\title{
Community Support in the Development of Rural Basic Schools in Ghana. A Study in the Assin South District
}

\author{
Robert Ampomah \\ Akenten Appiah Menkah University of Skills Training and Entrepreneurial Development \\ Faculty of Education and General Studies \\ Department of Interdisciplinary studies, College of Agriculture, Asante Mampong. \\ P. O. Box 40 Asante Mampong
}

\begin{abstract}
This study was to find out the support offered by the school community in addressing challenges faced by rural basic schools in the Assin South District of Ghana. The sample for the study consisted ten basic school headteachers, one hundred and forty teachers, and ten Parent Teacher Association chairpersons. The mixed method design was adopted. Respondents were selected using the purposive and convenience sampling procedures. Again, the study used questionnaire and interview guide as instruments for data collection. The study showed that the community support in education was significantly related to pupils' access and enrolment in basic education. Again, this study revealed that community support in the Assin South district related to school management. Furthermore, it was evident from the study that, there was a significant difference among the scores of schools with very good, good and poor community support in schools development programmes. Therefore, the hypothesis which state that the community support in school have significant effect on basic schools development in the Assin South District was supported. Based on the findings and conclusions the following recommendations were given:The District Education Oversight Committee should endeavour to educate stakeholders on their roles and responsibilities in educational management in the district during school durbars. The Ministry of Education and the Ghana Education Service should make it a policy the need for communities to support schools in their jurisdiction in areas such as building, maintaining and managing the schools. The Parent Teacher Association and the community leaders can build an environment in their areas through active concern and support for improving the quality of education. In doing this there should be good communication between the school and community. Regular parent-teacher meetings explaining the value of education. With this, parents will know the performance of their children on regular basis and if there is any shortfall, take remedial action for improving their children's education.
\end{abstract}

Keywords: Community support, challenges, basic education, rural, quality education

DOI: $10.7176 / \mathrm{JEP} / 12-9-02$

Publication date:March $31^{\text {st }} 2021$

\section{Introduction}

In recent years, the importance of education as a catalyst for personal, social and economic development has gained much prominence. As a result, various governments of Ghana on coming to office consider implementing various reform programmes to fine-tune education to ensure rapid socio-economic development of the country. This drive to improve education is evident from governments' commitment towards Universal Primary Education (UPE) at the world education declaration on Education for All (EFA) in 1991 and the implementation of the target 4 of the SDGs specifically to education that seeks to ensure inclusive and equitable quality education and promote lifelong learning opportunities for all by 2030. Targets $4 \mathrm{a}$ and $4 \mathrm{c}$ seek to build and upgrade education facilities that are child, disability and gender sensitive and provide safe, non-violent, inclusive and effective learning environments for all, and to substantially increase the supply of quality teachers, through international cooperation for teacher training in developing countries, especially least developed countries, Tamanjal \& Mwintribu (2017). Seeing education as a tool for national development, various policy reforms and committees on education have been set by different governments to help improve education delivery in Ghana (Broni-Afful and Ziggah, 2007). For the nation's quest for quality education to be attained, schools have been the structured institutions through which national aspirations could be transmitted. Truly, collaborated efforts by communities, Headteachers, Teachers, Circuit Supervisors, School Management Committee and Parent-Teacher Association also cannot go unmentioned in an effort to better our schools and for that matter Ghana's educational development effort.

In this era of technological advancement, there has been a clarion call to improve the quality of education to enhance the acquisition of 21 st century skills and competencies. At international, regional and national levels, efforts have been made by governments to overcome some of the challenges faced in schools at all levels irrespective of the school's location. The World Declaration on Education for All in the 1991 noted that poor quality of education is a hindrance to the socio-economic development of nations. There is therefore the need for stakeholders to come together to marshal the needed strength to shape our schools in the community for good.

Community support in school's development agenda is the process by which the community enter into mutual 
co-operation and team up to carry out some services to the school. According to Ogbonna (2003), it is the series of planned activities and medium through which the school seeks to learn about its community, to inform the community about, and interpret when necessary the purpose, programmes, problems and needs of the school and to involve the community in planning and evaluating school policies and progress.

Ghana as a lower middle income country has explored and continue to search for avenues to address various bottlenecks in school life in her bid to ensuring quality education. It should be remembered that there are myriads of definitions on quality education and these are often distinguished by issues related to outputs, outcomes, process or inputs (Adams, 2003). Quality in education is usually bound to interpretations of the user and often synonymous with effectiveness (Adams, 2003). Community support in school's life can be described as the degree of understanding and goodwill achieved between the school and the community. It therefore means that community support is that mutual understanding which binds the school and people within the community and where materials and other resources are geared to support the school and creates a favorable school environment for effective and efficient attainment of educational goals, Akpakwu (2012). Nakpodia (2013) asserts that a community through a healthy working relationship with the school manager and the entire school community would get to know the school's strength and weaknesses and find ways of improving the areas the school is lacking for the achievement of educational goals. Undeniably, health related issues, infrastructural deficit, poor pupil performance, teacher quality, misuse of instructional time among others continue to pose a challenge to successful organization of school in Ghana today at different grades of our educational ladder, (Adams, 2000; Ankoma et al., 2005).

Considering the intensity of international, regional and national dimension that education has assumed in the development paradigm, the researcher intends to assess the community in which the school is situated and the support it gives to alleviate the challenges faced by rural public basic schools in the Assin South District of Ghana.

\section{Problem Statement}

In an effort to improve basic education delivery in Ghana, the Millennium Development Goals (MDGs) and the efforts of Education for All (EFA), 1991 strategies have been captured in recent educational policies in Ghana. Previous strategies in Ghana have focused on providing support for deprived districts and particular demographic groups (e.g., out-of-school children, in the Schools for Life programme, Casely-Hayford \& Baisie (2007). These notwithstanding, basic education delivery in Ghana is problematic in terms of its quality. There is poor coordination among the decentralized educational structures, Hewlett Foundation (2008). Teacher quality and retention still remains a mirage. Scholars agree that teachers matter for students' learning, but there is much disagreement about how to best strengthen teaching quality (Johnson, 2012). Furthermore, there is wide agreement that some teachers are more effective than others but much debate about what factors matter most for teaching quality, (Bristol, 2014; Carey, 2014). As echoed earlier on teacher time on task, infrastructural deficit among others continue to bedeviled schools in Ghana and hampers quality teaching and learning. Though education in the country continue to be guided by various education Acts, and programmes, (Fielmua, 2012). Assin South district Basic Education Certificate Examination (BECE) core subjects (English Language, Mathematics, Social Studies and Integrated Science) pass rates in 2007 were below the national average. English Language (43.3\% vs. 76.5\%) and below the national average. In Mathematics it was (40.9\% vs. $75.1 \%)$ Etsey et al. (2009). It is not certain if communities support is available to basic schools in the Assin South District of Ghana in meeting key challenges such as access, enrolment and general school management in order to improve educational delivery and thus better educational outcomes.

\section{Purpose of the Study}

It is very common nowadays that majority of communities render various forms of support to their schools to compliment the effort of the government in school development. The Education Act of 1961 in Ghana made it imperative for Local Education Authorities (LEA) to build, equip and maintain schools within their jurisdiction, Graham (1976). Ever since, various educational reform programmes have sought the need to involve the community in different facet of school life including decision making, supplies, teaching and learning. The study was therefore undertaken to investigate the support of the communities in meeting the challenges faced by rural basic schools in the Assin South District of Ghana.

\section{Objectives of the Study}

The main objective of this study was to explore ways the community support in meeting the challenges faced by rural basic schools in the Assin South District of Ghana. Specifically, the study aimed at:

1. Identifying community support in access to rural basic schools in the Assin South district.

2. Finding out community support in enrolment drive of pupils in rural basic schools in the Assin district.

3. Finding out the support given by the community in managing rural basic schools in the Assin South district. 


\section{Research Questions}

1. How does the community support related to access to basic schools in the Assin South District?

2. How does the community support related to pupils enrollment in basic schools in the Assin South District?

3. To what extent does the community support related to basic school management in the Assin South District?

\section{Hypothesis}

$\mathrm{H}_{1}$ : Community support have significant effect on basic school development in Assin South District?

\section{0 literature review}

\subsection{Educational policy initiatives in Basic Education in Ghana}

Ghana gained independence in 1957 as a British colony and in 1960 accorded full Republican status. Prior to attaining political independence our educational goals were more often tied to the British educational programmes and goals. According to Little (2011), during the 1950s and 1960s the education system of Ghana was the envy of most Sub-Saharan African countries. This might be as a result of massive expansion of infrastructure in all parts of the country, access to basic and secondary education, high enrolment drive owing to the Accelerated Development Plan of Education in 1951 which was given a boost by the 1961 Education Act. Little, (2011) posits that between 1998 and 2006, our basic education saw an increase in enrolment again following the introduction of the 'capitation grant' policy designed to relieve parents of the burden of paying tuition fees in public basic schools. Since the early 1950s a number of policies to increase access to all levels of education have been implemented. Several of which are described in the Consortium for Research on Educational Access, Transitions and Equity (CREATE) country analytic review on Ghana (Akyeampong 2007).

Most researchers on the history of educational policy in Ghana agree that each successive policy text owes much to the policy themes set out in earlier texts (Fennell and Arnot, 2008; Little, 2011; Green et al., 2009). Recurring policy themes include the provision of free education and the need for a practical, vocationally oriented education. The call for free primary education goes back to the year 1951, and that for practical, vocationallyoriented education as early as 1847, during the British colonial period (Little, 2011). Furthermore, these recurring policy concerns include access, quality and costs, with varying emphases at different points in time. A recurring policy tension has been that between expansion of access and the quality of education, reflecting the tension between CREATE Ees Zones of Exclusion in which, in Zone 1, children are excluded from enrolling in school and in Zone 3, they are excluded from meaningful learning in school, once enrolled (Lewin, 2007).

The most radical reforms in basic education in the second half of the $20^{\text {th }}$ century are generally agreed to have been those set out in the report of the Commission chaired by Dzobo in 1973/4. According to Boateng (2012), the Dzobo report came out with a recommendation that there is the need to restructure the secondary school system and to re-orient the curriculum towards vocational skills. The recommendation and other reforms were implemented selectively and on an experimental basis. It was left to the then new military government of 1981 to renew the push for their comprehensive implementation through the 1987 reforms. By 1992, the right to free and compulsory education was enshrined in the new constitution, heralding another implementation push from 1995 through the "Free, Compulsory and Universal Education by 2005 Programme", known, more commonly, as fCUBE (Green et al, 2007). The fCUBE was linked closely to the Dzobo Commission proposals of 1974 and the 1987 reforms (Little, 2011).

Basic education in Ghana consists of 2 years of Kindergarten, 6 years of Primary Education followed by 3 years of Junior High School (GES, 2012). This indicate that pupils spend a total of 11 years at this level of education. As outlined in the United Nation's Millennium Development Goals, Ghana wants to achieve universal basic education by 2015. In order to increase access to basic education, the government introduced the Capitation grant. This initiative took care of tuition fees and made basic education free (UNESCO, 2011).

The school feeding programme was yet another bold government policy to ensure that pupils of school going age at the basic level have at least a meal at school and to attract more children to school, Osei-Fosu (2011). Despite the gains, progress is not completely achieved and the quality of basic education has only improved marginally.

\subsection{Challenges Faced by Rural Basic Schools in Ghana}

Hewlett Foundation (2008), indicates that some of the major challenges faced by rural basic schools that affect quality education broadly include poor coordination among the decentralized educational structures, health related issues, instructional materials, poor pupil performance, teacher quality, instructional time, motivated and qualified teachers, appropriate curriculum, well equipped library, appropriate language teaching, appropriate class size and favourable school environment.

Ampiah \& Yamada (2008) however are of the view that rapid expansion of basic education in Ghana would undermine quality provision especially where no effective strategies are in place to train and retain teachers. There 
is therefore the potential risk to initial gains in enrolment since demand may soften if quality deteriorates. With regard to quality and relevance, it is generally agreed that more needs to be done. Unfortunately, the quantitative aspect of education rather than the qualitative aspect has become the main focus of attention in recent years for policy makers and governments (UNESCO, 2004). Quality of education seems to have become a subordinated priority to quantity of education as a result of policies seeking to improve educational access (Govinda \& Bandyopadhyay 2010). What seems to be equally important is how resources put into schools and classrooms are utilised to promote quality education Ampiah \& Yamada (2008). The poor quality of pupil learning reflects the poor quality of teaching in Ghana. Most teachers lack supervision and feedback on their instructional practices (Wahlstrom and Louis, 2008). This seem to be the picture of Ghana's basic education. Improving basic education in Ghana also depends on effective supervision and monitoring. Although, the GES has designed an administrative structure including an Inspectorate Division of the GES and the establishment of circuit supervision with supervisors in all circuits within an educational district, supervision is perceived to be extremely weak and ineffective (MoESS, 2008). The major concern of unequal access to quality basic education of the rural areas visa-vis the urban centres has marginalized the children in rural areas who also want to have access to the same system and standard of education as it is in the urban settings.

Poor classroom and furniture condition in the school, inadequate textbooks, reading and teaching/learning materials, education and sports equipment and lack of library and computer laboratory especially in remote areas affects teaching and learning. These inadequacies undoubtedly holds back the pace of educational delivery and development in Ghana and results in a huge gap between children from rural and urban areas in terms of quality education. Inadequate funding, weak monitoring and evaluation, insufficient relevant curriculum, inadequately trained and poor distribution of teachers and low levels of community involvement were highlighted as some of the major drawbacks to Ghana's realization of the overall EFA goals, especially those relating to quality and equity outcomes in basic education, (Edzii, 2017; UNESCO, 2015, p.6 cited by Ackah, 2019).

\subsection{Providing Quality Basic Education in Rural Communities}

Quality is at the heart of education and what takes place in the classroom and other learning environment is fundamentally important to the well-being of children, young people and adults. Watkins (2000) asserts that quality is never an accident; it is always the result of high intention, sincere effort, intelligent direction and skillful execution, which represents the wise choice of many alternatives. Watkins further argues that, quality is not an act but rather a habit. Quality education is one that satisfies basic learning needs and enriches the lives of learners and their overall experiences of living. Ministerial Round Table discussion on quality education by UNESCO (2005), indicates that quality has become a dynamic concept that constantly been adapted to a world whose societies are undergoing social and economic transformation. Quality education should therefore equip all men and women to become fully participating members of their own communities and also citizens of the world. UNESCO (2005), quality education has now become a universal goal which is a prerequisite for education and sustainable development. This is a goal which all countries have to strive to attain in order to fit into the global village. Hence, Eyiah (2006), says quality education is the character of the set of element in the input, process and output of the school that provides services that completely satisfy both internal and external strategic school constituencies by meeting their explicit and implicit expectations. This is supported by Louis and Smith (1990) when they identified seven quality of work by teachers that results in quality basic education. These were: respect from relevant adults, such as the administrators in the school and district, parents and the community at large; participation in decisionmaking that augments the teachers' sense of influence or control over their work setting; frequent and stimulating professional interaction among peers (e.g. collaborative work/collegial relationships) within the school; structures and procedures that contribute to a high sense of efficacy (e.g. mechanisms permitting teachers to obtain frequent and accurate feedback about their performance and the specific effects of their performance on student learning; opportunity to make full use of existing skills and knowledge, and to acquire new skills and knowledge (selfdevelopment); the opportunity to experiment; adequate resources to carry out the job; a pleasant, orderly physical working environment; a sense of congruence between personal goals and the school's goals. Other factors that may contribute to teachers' satisfaction are task differentiation and possibilities to make promotion and financial incentives.

\subsection{Community participation in school}

In the past, community participation in school was characterized by volunteers, mostly mothers, assisting in the classroom, chaperoning students and fundraising, Epstein \& Connors (1995). Headteahers and other stakehoders in schools need to become coalition builders today as managers of the internal running of schools themselves. Bakwai (2013) points out that community participation in school is a two-way symbiotic arrangement through which the school and the community cooperate with each other for realization of goals of the community and vice versa. Therefore, a school is a mini society that needs a good relationship with the community for it to function effectively. On the other hand, the community also need the school for its survival and progress. Strong school 
and community ties, including opportunities for shared leadership, climate of safety and trusting relationships will result in effective school. School community relationship can be seen as the co-ordination of the efforts of people in the community and those in the school towards the achievement of the broad and specific goals of education. It is the degree of understanding and goodwill, which exists between the school and the community (Okorie, Ememe \& Egu 2009).

School as an open system and a social organization thrives on the effective interrelationship within it and with its relevance. According to Okam and Bozimo (2004), this community partnership involves the inter-linkage association and cooperation between a school and the host community. It is also concerned with bringing human resources in the community and school for effective and functional school management, with the central focus of enhancement of teaching and learning. Through appropriate community partnership, the school comes into factual contact with the community issues and address them accordingly. Since schools are established for serving societal needs; it becomes necessary that good partnership must exist between the school and the community it is meant to serve. Madumere (2004) is of the view that the school as a social system means that the school is part and parcel of the society. Madumere further reiterates that the sociologist sees the school as belonging to the community that builds it. This is supported by Oniyangi (2008), who maintains that the school as an entity which has the responsibility of molding, raising and shaping responsible individuals in the society do not exist in a vacuum and may not work effectively without the host community. The needed efficiency and effectiveness of a school as an educational institution may not be possible if the influence of the community is not taken into consideration in the process of teaching and learning. To Aminu (2006), the responsibility of influencing and shaping the behaviour of youths is a collective responsibility of both the school and the community where the school is situated. Indeed literature search points to the fact that the school and the community are inseparable. The exchange of ideas between the school and the community on educational plans, policies, programmes, means and ends is necessary if accomplishment of educational goals is to be possible. The school head and staff need to have a good working relationship with the community in order to effectively achieve the general and specific objectives of the school.

Obi (2004) notes that school community relationship can take place between the school and the school's parent-teacher association, old students association, school committees, school board of governors and school proprietors' association. This will help them know better the challenges of the school and may provide assistance that may bring effectiveness and efficiency in the educational system. It is as a result of this that Nakpodia (2013) admits that a community through a healthy working partnership with the school manager and the entire school community would get to know the school strength and weaknesses and find ways of improving the areas the school is lacking for the achievement of educational goals. This partnership enables the school and the community to share the responsibility of running the schools and helping the child to achieve the aim of education without which neither the school nor the community can benefit (Tondeur, 2013). It is as a result of this that Henderson and Mapp's (2002) postulate a broad range of engagement strategies on a variety of leaners outcomes. These include; achievement, attendance, grade promotion and retention, school facility improvements, school leadership, staffing and programme quality as a results in positive and convincing partnership between family and school. These always happen when there is effective school community partnership. A study by the World Bank (1997, cited in Chapman \& Agams 2002) revealed that involvement of the community and commitment of its resources into schools organization and management to some extent support and influence teaching, learning and quality of education. Among the potential advantages of closer linkage of community in school life is the possibility for more involvement of pupils and students, teachers and parents in data collection, verification, analysis and use in an interactive process. This may be seen as part of a local process of inquiry which, in itself, is part of a process of sustaining improvement, Chapman \&Adam (2002). Kendall (2007) however, notes that there is limited evidence available about community interaction and assessments, classroom-based language usage, student and parent expectations for educational outcomes and the effects of changing monitoring and administrative practices in decentralizing education systems. This lack of information significantly constrains "evidence-based" arguments regarding community's role in quality improvement at the school and system levels. (Dunne et al., 2007) argue that there is limited research on how community partners actually collaborate with schools to address issues of access, attendance, completion and other local education problems and it effects.

\subsection{Research Methodology}

\subsection{Research Design}

Research design is the attempt by the researcher to specify the methods and the needed procedure to get information for the study Green and Tull (2009). This study adopted the sequential mixed method design, Creswell (2003). The study administered a questionnaire and interviewed the PTA chairpersons. This design was used in order to ascertain some outstanding claims made by the participants (PTA chairpersons) while ensuring the completion of the questionnaire. Again, this design serves the purpose of cross-validation and allows the study to benefit from the strengths inherent in both quantitative and qualitative methods, Yin (2009). 


\subsection{Population, Sample and Sampling Technique}

All the headteachers and teachers in the ten selected basic schools, in the rural communities and their PTA chairpersons were the respondents for the study. The purposive sampling procedure was used to select ten (10) headteachers while one hundred and forty (140) teachers were selected using the convenience sampling procedure. In each school the headteacher and fourteen teachers comprising Kindergarten, Primary and Junior High School teachers were chosen. Bringing the total population of headteachers and teachers to one hundred and fifty (150). Again, ten (10) PTA chairpersons were interviewed. In all, there were one hundred and sixty (160) respondent in the study.

\subsection{Data Collection Instrument}

In order to achieve the purpose of this study, the researcher used questionnaires and interview guide as the main data collection instruments. The questionnaires were given to the headteachers, and teachers whiles the interview guide were for the PTA chairpersons. After analyzing the responses from the questionnaires, the interview was conducted to confirm the claims by the respondents of their activities regarding the support of the community in addressing challenges faced by rural basic schools in these selected communities in the district.

\subsection{Data analysis}

All the research questions were answered using Pearson zero-order correlation matrix. However, the hypothesis of the study was tested using One-Way ANOVA to compare the variation between groups (levels) and the variation within samples by analyzing their variances. The interviews conducted with the PTA chairperson were transcribed.

\section{Results and discussion}

\section{Research Question 1: How does community support related to access to basic schools in the Assin South District?}

Pearson zero-order correlation matrix was used to establish the relationship. The result of the Zero-order correlation between community support and access to basic education is presented in Table 1 .

Table 1: Community support and access to basic education

\begin{tabular}{llc}
\hline \multicolumn{3}{c}{ Access to basic education } \\
\hline Community support & Pearson Correlation & $.574 * *$ \\
& Sig. (2-tailed & .000 \\
& $\mathrm{~N}$ & 150 \\
\hline
\end{tabular}

**. Correlation is significant at the 0.01 level (2-tailed)

Table 1 reports Zero-order correlation coefficients between community support and access to basic education in the Assin South district. The Zero-order correlation coefficients obtained are $r=0.574^{* *}$. This is positive with $\mathrm{p}$-value $=.000$ which is less than alpha $=0.01$. This suggests that community support was significantly related to pupils' access to basic education.

When schools and community organizations work together to support learning everyone benefits. Partnerships can serve to strengthen, support and even transform individual partners, resulting in improved programme quality, more efficient use of resources and better alignment of goals and curricula (Harvard Family Research Project, 2010). Again, Blenck, Melaville \& Shah (2003) argue from their evaluation review that successful community support built on more than good intention lead to effective leadership, access and resource. Community support in school increases a sense of community ownership and a better understanding of the true nature of the educational problems facing a country. This enable stakeholders in the community contribute to improvement in education through improving student recruitment, retention and attendance; improving teachers' performance and condition of their service. However, Dunne et al., (2007) disagree with the findings and argue that there is limited research on how community partners actually collaborate with schools to address issues of access, attendance and other local education problems.

Research Question 2: How does community support related to pupils' enrollment in basic schools in the Assin South District?

Research question two also sought to establish the relationship between community support and enrollment in basic school. The Zero-order correlation was therefore used to assess the relationship between community support and enrollment in basic schools. Table 2 shows the findings.

Table 2: Community Support and Enrolment drive in Basic Schools

\begin{tabular}{ccc} 
& & Enrolment in Basic Education \\
\hline Community support & Pearson Correlation & $.684^{* *}$ \\
& Sig. (2-tailed) & .000 \\
$\mathrm{~N}$ & 150 \\
\hline
\end{tabular}

**. Correlation is significant at the 0.01 level (2-tailed)

Table 2, reports Zero-order correlation coefficients obtained on community support and enrolment in basic 
school.

$\mathrm{r}=0.684^{* *}$. This is positive with $\mathrm{p}$-value $=0.000$ which is less than alpha $=0.01$. This implies that community support was significantly related to pupils' enrollment in basic school.

Findings from this current study support views expressed by some researchers such as Baku \& Myers (1994). According to Baku \& Myers community (parent-teacher) cooperation in educational provision contributes to improvement in the enrolment and retention of pupils and overall quality and long-term impact of education. The findings again support a study in Kenya where the central government's grant, twice a year, deposited directly into school's bank account to be administered by a committee of teachers and community members (parents) brought a great success in terms of increased enrolment in primary school (Makori, 2003).

Research Question 3: To what extent does community support related to basic school management in the Assin South District?

This research question sought to find out the relationship between community support and basic school management. The Zero-order correlation was therefore used to find out the relationship between community support and basic school management. The result is presented in Table 3.

Table 3: Community Support and Basic School Management

\begin{tabular}{ccc} 
& & Basic School Management \\
\hline Community support & Pearson Correlation & $.723^{* *}$ \\
& Sig. (2-tailed) & .000 \\
& $\mathrm{~N}$ & 150 \\
\hline
\end{tabular}

**. Correlation is significant at the 0.01 level (2-tailed)

Table 3, reports Zero-order correlation coefficients between community support and basic school management is $r=0.723^{* *}$. The coefficient is positive with $\mathrm{p}$-value $=0.000$ which is less than alpha $=0.01$. This indicates that community support was significantly related to basic school management.

The findings from my study corroborate with the views of Amofa, (1999) which states that the closed system type of community and school partnership is very prevalent in rural areas. However, (Annoh, 2003), believes that this closed system of community partnership has contributed to less community involvement and commitment in the quality management of education in Ghana and the Tolon/Kumbungu District of Northern Region in particular and this unhealthy community partnership with school in the Tolon/Kumbungu District manifests itself in areas like attacking school authorities and encroachment of school lands.

\section{Hypothesis Testing}

The hypothesis was tested using One-Way ANOVA with the level of significance $=.01$. This means when the Pvalue obtained is less than .01 , then $\mathrm{P}$ - is significant. This means that there are significant differences among the respondents.

To test the hypothesis which states that community support in schools have significant effect on basic schools development in the Assin South District using the One-Way ANOVA, the results are presented in table 4 and 5. Table 4. Means and Standard Deviations of Community Support in School Development

Level of community

\begin{tabular}{lccc} 
Support & Number & Mean & Standard deviation \\
\hline Very good & 52 & 65.8800 & 14.41320 \\
Good & 54 & 57.1964 & 17.55968 \\
Poor & 44 & 54.3938 & 14.95466 \\
\hline Total & 150 & 59.2234 & 17.55968 \\
\hline
\end{tabular}

Table 5. One-Way ANOVA Results on Community Support in School Development

\begin{tabular}{llrlll}
\hline Source & Sum of squares & Df & Mean Square & F & P \\
\hline Between group & 3991.405 & 3 & 1330.468 & 5.594 & .000 \\
Within group & 44710.511 & 147 & 237.822 & & \\
\hline Total & 48701.916 & 150 & & & \\
\hline
\end{tabular}

Results from tables 4 shows that there is a significant difference among the scores of schools with very good, good and poor community support in schools development. Again, table 5 shows a significant differences among scores obtained. $\mathrm{F}(150)=5.594, \mathrm{p}<.01$. It is clear that community supports have significant effect on school development. Therefore, the hypothesis which states that community support have significant effect on basic schools development in the Assin South district was supported.

Excerpts from Interview with PTA chairpersons

All PTA chairpersons claimed an open door policy in their school in an attempt to ensure the betterment of their school. One described this saying: "I always say to parents that they should phone to findout the problems of the school for support and to see how their wards are faring from class teachers and the school head within 24 hours." The interview revealed that many parents are received by contacting a school and especially the 
headteachers. Moreover, headteachers were inundated by parental demands on their time. Another PTA chairperson said that he always visits homes of pupils with the support of the head in cases of repeated absenteeism or suspected child neglect. Again, the data showed that parent-teacher meetings focused on the teachers' telling parents about activities and how children were progressing in all spheres of their life in school.

In building a successful community support another PTA chairperson established that a number of school procedures are put in place to own the school as community members and to ensure staff and pupils' wellbeing. One of the most important emphasis was on teamwork. She reported that people were more likely to stay involved in school work if they had opportunities to collaborate. Hence, always ensuring much more teamwork and any kind of interactive planning together in resolving school challenges such as absenteeism, supporting teaching and learning with resources and encroachment of school lands.

\section{Findings}

Results from the study revealed a positive relationship between community support and access to basic education. Again, there is a correlation between community support and basic school enrollment as well as basic school management in the Assin South District of Ghana in promoting quality education delivery. Findings from the current study established a significant relationship between community support and quality education in the Assin South District of Ghana.

\section{Conclusions}

The study was design to find out the support given by the community in addressing challenges faced by rural basic schools in the Assin South District of Ghana. The sequential mixed method was adopted by the researcher to describe and document aspects of the situation. This design helped the researcher to survey the communities to have in-depth knowledge and to see some of the challenges faced by the rural basic schools in the district.

The target population for this study was all headteachers and teachers in the selected rural communities schools and their PTA chairpersons. Also, the study adopted statistical tools such as Pearson zero-order correlation matrix and One-Way ANOVA to analyze the findings from the respondents.

On the basis of the findings it suffices to conclude that community support has an influence on many educational programmes and consequently school development. Undoubtedly, the initiative is a good one, therefore, every frantic effort should be made to educate community members to sustain it and to make it a policy issue in drafting educational policies and programmes as it happened during the colonial and immediate postcolonial periods in Ghana.

\section{Recommendations}

The following recommendations were made in line with findings of the study:

- The study revealed that community support affects access, enrolment drive and management of basic education in the Assin South District. It is therefore recommended that the District Education Oversight Committee should endeavour to educate stakeholders, especially community members on their roles and responsibilities in educational development during durbars.

- The Ministry of Education and the Ghana Education Service should make it a policy that it is obligatory for the community to support schools in its jurisdiction. They are to ensure the building, equipping, maintaining and managing of their schools.

- The Parent Teacher Associations and the community leaders can build an environment in the community through active concern and support for improving the quality of education. In doing this, there should be good communication between school and community. Regular Parent Teacher Association meetings explaining the value of education. Through this, parents will know the performance of their children on regular basis and if there are any shortfalls, remedial actions taken to improve their children's education.

\section{Ethical consideration}

Ethical considerations are principles which bind the researcher in conducting the research. The researcher sought for the necessary permission from the key respondents and discussed with them the essence of the study. They were assured of confidentiality; this means information from the respondents will remained confidential. The names and any form of identification that could be associated with the respondents were completely ignored because such information will not be included in the report. Moreover, prior to volunteering information, the respondents (teachers and PTA chairpersons) were given enough information regarding the study and participation of respondents was voluntary.

\section{Acknowledgement}

I am indebted to the headteachers, teachers and the PTA chairpersons who allowed me to conduct the study in their schools. For willingly participating in the study to shed light on school and community support, I say a big 
thank you.

\section{References}

Ackah, A. M (2019). Enacting Relevant Basic Education to Bridge the Rural-Urban Inequality in Ghana; The Prospects and Approaches for Investigating Rural Educational Realities. International Journal of Humanities and Social Sciences Vol. 11, No. 1.

Akpakwu, O. S. (2012). Educational management: Theory and practice. Makurdi. Destiny Ventures.

Akyeampong, K. (2007). 50 years of educational progress and challenges in Ghana. Sussex, UK: University of Sussex.

Aminu, J. (2006). Quality and stress in Nigerian education. Zaria: University Press.

Ampiah, J.G. \& Yamada, S. (2008). UPE Policy Implementation in Ghana: Challenges and Policy implications. Amofa, A. (1999). Sociological foundation in education for schools. Kumasi: Saviour Printing Press.

Annoh (2003, cited in Amofa 1999). Sociological foundation in education for schools. Kumasi Saviour Printing Press

Ankomah, Y. Koomson, J. Bosu, R. and Oduro, G K. T. (2005). Implementing Quality Education in Low Income Countries. Ghana: University of Cape Coast.

Adams, D. (2000). Education and National Development: Priorities, Policies and Planning. Asia: The University of Hong Kong.

Adams, D. (2003). Defining education quality. Asia: University of Hong Kong.

Baku, J. J. K., \& Myers, E. K. (1994). Evaluation of the equity improving programme in Ghana. Accra: USAID/MOE.

Bakwai, B. (2013). Assessment of school community relationship in secondary schools in Zamfara State. Unpublished Research Dissertation. Department of Educational Foundations. Usmanu Danfodiyo University, Sokoto.

Boateng, C. (2012 a). Leadership Styles and Effectiveness of Vocational Technical Institutions in Ghana. American International Journal of Contemporary Research. 2(3). pp. 128-134.

Bristol, T. J. (2015). Teaching boys: towards a theory of gender-relevant pedagogy. Gender and Education, 27(1), $5-68$.

Broni, A \& Ziggah R. S. (2007). Introduction to Curriculum Development in Ghana. Accra - Ghana: Yamens Press Limited.

Blenck, M., Melaville, A., \& Shah, B. (2003). Making the difference: Research and practice in community schools. Washington, DC: Coalition for Community Schools.

Carey, R. L. (2014). A cultural analysis of the achievement gap discourse: Challenging the language and labels used in the work of school reform. Urban Education, 49(4), 440-468.

Casely-Hayford, L. \& Baisie, A. (2007). The Leap to Literacy and Life Change in Northern Ghana: An Impact Assessment of School for Life. Final Report (Abridged Version). Accra: School for Life.

Chapman, D. \& Adam, D. (2002).The Quality education: dimensions and strategies. Education in developing Asia, vol. 5 .

Creswell, J. W. (2003). Research: qualitative, quantitative and mixed methods approaches. Thousand Oaks, C A:Sage.

Dunne, M., Akyeampong, K. \& Humphreys, S. (2007). School Processes, Local Governance and Community Participation: Understanding Access. CREATE, Research Monograph, No.6 London: University of London.

Etsey, K., Smith, T. M., Gyamera, E., Koka, J., de Boer, J., Havi, E., \& Heyneman, S. P. (2009. Review of basic education quality in Ghana: Progress and problems. Final report. Washington, DC: USAID.

Epstein, J. \& Connors, L. (1995). School and family partnerships in the middle grades. Creating school / family partnerships, 137-166.

Eyiah, J. K. (2006). Brief history of state education in Ghana: Longman.

Fennell S. Arnot M. (2008). Revisiting education and development agendas: Contemporary gender research. In: S Fennell and M Arnot (eds) Gender Education and Equality in a Global Context, pp. 1-16. London: Routledge

Fielmua, R. D. Boye B. (2012). British Journal of Arts and Social Sciences, 2012

Graham, C. K. (1976). The History of Education in Ghana. Ghana Publishing Corporation, Tema.

Green, P. E., Tull, Donald S. (2009). Research for marketing decisions. (3rd. Ed). Englewood Cliffs, New Jersey: Prentice-Hall.

Ghana Education Service (2012). Head teachers' handbook. Ghana: GES. Pg. 5.

Govinda, R., \& Bandyopadhyay, M. (2010). Social exclusion and school participation in India: Expanding access with equity. Prospects, $1-18$.

Hewlett Foundation, (2008). The quality education in developing countries initiative, Grant making Strategy, p. $1-4$.

Harvard Family Research Project. (2010). Partnerships for learning: Promising practices in integrating school 
and out-of-school time program supports. Retrieved from http://www.hfrp.org/

Henderson, A. T., \& Mapp, K. L. (2002). A new wave of evidence: The impact of school, family, and community connections on student achievement. Austin, TX: National Center for Family and Community Connections with Schools.

Johnson, S. M. (2012). Having it both ways: Building the capacity of individual teachers and their schools. Harvard Educational Review, 82(1), 107-122.

Kendall, N. (2007). Parental and Community Participation in improving educational Quality in Africa: Current Practices and Future Possibilities. International Review of Education, November 2007, Vol. 53, issue 5-6, pp.701-708.

Lewin, K. M. (2007). Expanding Access to Primary and Secondary Schooling: Long Term Planning for EFA and the MDGs Commissioned study for the Department for International Development Advisors. Published in

Pathways to Access: Research Discussion paper No 8, CREATE, Centre for International Education, University of Sussex.

Little, P. (2011). Expanded learning opportunities in Washington state: Pathways to student success. Retrieved from http://www.schoolsoutwashington.org/

Louis, K.S. \& Smith, B.A. (1990). Teachers' work: Current issues and prospects for reform. In: P. Reyes (Ed.), Productivity and Performance in Educational Organizations [pp.23-47]. Newbury Park: Sage.

Makori, A. (2004). Implementation of universal primary education in Kenya: An analysis of its Impact and progress towards achieving the EFA goal in Kisii District.

Madumere, S. C. (2004). Social \& Philosophical Aspects of Educational Planning. Lagos: Vita Nasco Publishing Co.

Ministry of Education, Science and Sports (2008). Education Sector Performance Report, P, 79. Ghana: MESS.

Nakpodia, E. D. (2013). School community relations as panacea for community Involvement in secondary schools development in Nigeria. Journal of Research in Education and Society, 4(1), 44-52.

Obi, E. (2004). Education Management. Enugu: Computer Edge publishers.

Ogbonna E, Wilkinson B (2003). The false promise of organizational culture change: A case study of middle managers in grocery retailing. Journal of Management Studies 40: 1151-1178.

Okorie, N. C., Ememe, O. N. \& Egu, R. H. N. (2009). School-community relations in the development of secondary schools: A focus on Aba Educational Zone. African Journal of Education and Development Studies, $6(1), 22-38$

Okam, C. C. \& Bozimo, G. O. (2004). Forging an effective school-community relationship in implementing the curricular issues intrinsic in Nigeria universal basic education at the primary school level. Nigerian Journal of Curriculum Studies. 8, 11, 232-239.

Oniyangi, S. A. (2008). Strategies for promoting school and community relationship for better productivity. In D. O.

Durosaro, R. A. Shehu and K. Mohammed (eds.), Classroom management techniques for the newly recruited primary school teachers in Kwara State (pp. 99-110). A publication of Kwara State Universal Basic Education Board, Ilorin.

Osei-Fosu, A. K. (2011). Evaluating the impact of the capitation grant and the school feeding programme on enrollment, attendance and retention in schools: The case of Weweso Circuit. Journal of Science and Technology (Ghana), 31(1).

Tamanja \& Mwintribu (2017). Research Fellow, National Centre for Research into Basic Education (NCRIBE), Institute for Educational Research and Innovation Studies (IERIS), University of Education, Winneba (UEW), GHANA.

Tondeur, N. (2013). Roles, Duties and Responsibilities of School Management Team: Training Manual for Secondary School Managers. Kigali.

UNESCO (2011). ICT Competency Framework for Teachers: Paris.

UNESCO (2004). Report to UNESCO, International Commission on Education for twenty-21 $1^{\text {st }}$ century. Paris, France.

UNESCO (2005). Challenges of Implementing Free Primary Education in Kenya: Experience from the Districts. Nairobi: UNESC.

UNESCO (2005). Global monitoring report. New York: USA.

Wahlstrom, K. L. \& Louis, K. S. (2008). How Teachers Experience Principal Leadership: The Roles of Professional Community, Trust, Efficacy, and Shared Responsibility. Educational Administration Quarterly, 44, 458-495.

Watkins D. (2000) Learning and Teaching: A cross-cultural perspective, School Leadership \& Management, 20:2, 161-173.

Yin, R. K. (2009). Case study research: design and methods (4 ${ }^{\text {th }}$ ed.). California: Sage Publications. ISBN 978-1 4129-6099-1. 